\title{
A Review and Scientometric Analysis of Supply Chain Management (SCM)
}

\author{
Haydar Yalcin \\ Department of Information Management, Izmir Katip Celebi University \\ Havaalanı Şosesi Cd. Aosb No:33 D:2, 35620 Çiğli/İzmir, Turkey \\ Email:haydar.yalcin@gmail.com \\ Wanying Shi \\ The School of Business, Portland State University \\ 631 SW Harrison St., Portland, OR 97201 \\ Email: wanyshi@pdx.edu (Corresponding Author) \\ Zafrin Rahman \\ The School of Business, Portland State University \\ 631 SW Harrison St., Portland, OR 97201 \\ Email: zafrin@pdx.edu
}

\begin{abstract}
This paper aims to provide the most up-to-date review of supply chain management (SCM) publications through the use of scientometric analysis by reviewing studies published between the years 1998 to 2017 . Global contributions in the field of SCM are well illustrated by identifying top productive journals, scholars, institutions, and countries. To clearly identify prevailing and recent research trends and topics in the field, the papers reviewed were categorized into three stages based on the timeline and increasing rate of publications. In each stage, core research topics and research methods were explored. The results of this study show that out of 13477 research outputs, the highest percentage of $59.38 \%$ are research articles, and the lowest percentage of $0.33 \%$ are books. The majority of 2389publications originated from the United States, followed by 2256 from China. We observed a general increase in the number of publication records in SCM over the years. The areas of current research interests and future research needs in the SCM area are also identified.
\end{abstract}

Keywords: supply chain management, web of science, scientometric analysis, literature review

\section{INTRODUCTION}

Supply Chain Management (SCM), initially introduced by Oliver and Webber (1982), has gained tremendous interest in both academia and industry. Since then, practitioners and academics alike have tried to identify various ways to improve and manage supply chains which are used to solve complex problems and challenges faced modern and dynamic industries and economies. Under the umbrella of SCM, research topics such as supply chain coordination, supply chain resilience, reverse logistics, supply chain integration, supply chain finance, and green supply chain are explored to benefit SCM development. In today's world of globalization where pressing demand on product variety, innovation and offshore production volume are at their peaks, supply chain issues are no longer simple but involve complex systems which include international material flow, financial flow, foreign policy, social responsibility, business risks, and so forth. Thus, SCM remains a discipline that requires significant scholarly attention.

A number of articles reviewing the literature in SCM have been completed over the past decade. The majority of these reviews focus on specific aspects of SCM such as green supply chain development (Fahimnia et al., 2015; Mishra et al., 2017), corporate social responsibility (Tate et al., 2010; Feng et al., 2017), supply chain finance (Gelsomino et al., 2016; Xu et al., 2018), sustainability (Ahi et al., 2016; Wang et al., 2017), big data (Schoenherr and Speier-Pero, 2015; Mishra et al., 2018) orrisk management (Colicchia and Strozzi, 2012; Ho et al., 2015). There are also some reviews concentrating on SCM of a particular industry such as automotive industry (Gonzalez-Benito and Lannelongue, 2013), fashion (Sen, 2008) or agri-food (Luo et al., 2018) while other articles review SCM publications of a particular journal such as IJPR (Kazemiet al., 2018) and SCMIJ (Velmurugan and Radhakrishnan, 2015; Kumar and Kushwaha, 2015). Very few review articles have generally covered the entire SCM field using scientometric analysis method (Charvet et al., 2011; Shiau et al., 2015), and none of them addresses the specific research questions tackled in this study.

This study contributes to the SCM literature by providing the most up-to-date insight into the field of supply chain management through conducting scientometric analysis on studies published between the years 1998 and 2017 comprehensively. This review pursues four main research objectives: (1) Track the evolution of the SCM research field; (2) Identify top productive authors, organizations, and countries contributing to SCM literature; (3) Recognize a list of influential journals for SCM research work; (4) Identify research interest clusters and deduce emerging research themes in SCM. 
The remainder of the paper is organized as follows. Section 2 provides an overview of supply chain management development based on the extant literature. Section 3 introduces the research methodology and Web of Science (WoS) database, both of which are used to identify the literature that will be evaluated in this study. Detailed scientometric analysis and the corresponding results are discussed in Section 4. Section 5summarizes the results, presents the limitations of the study, as well as sheds light on future work.

\section{SUPPLY CHAIN MANAGEMENT DEVELOPMENT OVERVIEW}

The evolution of SCM can be traced back to the 1950s and 1960s (Tan, 2001) when mass production dominated manufacturing activities but little attention was paid to inventory or supplier relationship management which can lead to high inventory costs. Fortunately, manufacturing resource planning (MRP) as a manufacturing strategy was introduced in the 1970s (Jacobs and Chase, 2017) that emphasizes the effective planning of resources within a manufacturing company so as to achieve high performance in terms of low inventory cost, high product quality, and shortened lead time. Jacobs and Chase (2017) stated that, the development of Just-in-time (JIT) in the 1980s is a revolution in production which integrates activities to perform highvolume production with minimum inventory, and with JIT, the inventory arrives at the production line right at the moment that it is needed. To realize lean inventories for production, in addition to materials flow management, supplier relationship management is of vital importance, and this brings the emergence of SCM.

In the 1990s, SCM studies mainly focused on the definition and conceptual framework of the supply chain process. Different scholars define SCM from different perspectives, which has led to quite a few definitions of SCM in the literature. For example, New and Payne (1995) concentrated on the strategic importance of physical distribution and logistics when defining SCM. Cooper et al. (1997) did a thorough comparison between logistics and SCM, and advocated the need for the integration of supply chain operations that went beyond logistics activities. Another broad definition of SCM focuses on integrating all of the organizations involved in the value chain, covering supply chain operations and activities of planning, sourcing, product design, manufacturing, distributing, warehousing, logistics, and customer support service (Baatz, 1995; Farley, 1997).

As organizations started becoming more aware of environmental protection and social responsibility issues, sustainable and green supply chain management started to gain popularity from the 2000s onwards. Ahi and Searcy (2013) defines sustainable supply chain management (SSCM) as integrating environmental, economic, and social responsibility into supply chain coordination. Green supply chain management (GSCM) is one aspect of SSCM with emphasis on environmental friendliness. GSCM is defined as integrating environmental concerns into supply chain operations and management including reverse logistics (Fahimnia et al., 2015). Moreover, supply chain management concepts and techniques have been applied in particular industries. Wen et al. (2019) did a systematic review of fashion retail supply chain management by including the functional areas of manufacturer, retailer, consumer, and the entire supply chain system. Habib (2017) presented the theory and evolution of SCM development in different manufacturing and service industries in terms of time frame through a large scale empirical study. Chien and Shih (2007) investigated green supply chain management practices in the electrical and electronic industry in Taiwan. Zhang et al. (2009) provided a systematic review of tourism supply chain management, where the characteristics of tourism products, core issues, and the tourism supply chain framework were presented. Combining SCM research with industry practices benefits particular industries with guidance for more effective operations and decision making.

Supply chain finance (SCF), the merger of SCM and trade finance, has attracted a great deal of attention from both practitioners and researchers since the 2008 global financial crisis. SCF aims to provide solutions for capital-constrained supply chains. SCF has been applied to both two and moreechelon supply chain models with new coordinating mechanisms being investigated for higher supply chain efficiency (Shi, 2016; Shi and Drzymalski, 2017). Vousinas (2018) provided an up-to-date systematic literature review of both theoretical and empirical SCF studies and also shed light on emerging areas such as SCF Bullwhip effect and blockchain applications. Similarly, the paper by Wang, Han, and Beynon-Davies (2019) systematically reviewed blockchain, examined the current state of blockchain technology diffusion within supply chains, and presented ways in which blockchain can potentially influence future supply chain practices and policies.

Recently, in response to industry 4.0 requirements, digitalized supply chain including Internet of Things (IoT), cloud computing, and information system integration have been developed to more quickly respond to changing customer demand and make quicker real-time decisions. Manavalan and Jayakrishna (2019) demonstrated various aspects of IoT and industry 4.0 and explored the potential IoT opportunities in advancing sustainable supply chain development. Gupta et al. (2017) did a review of the role of big data in humanitarian supply chain management with a focus on saving lives using scarce resources. With today's business environment becoming more and more dynamic and complex, the ways in which industry and organizations can benefit from SCM with the most state-of-art information and technology remains an important and popular topic in academia and practice.

\section{RESEARCH METHODOLOGY}

The scientometric analysis method was employed in this study to achieve the predefined research objectives of evaluating the contributions of the researches in the SCM area, exploring research interest trends, and deducing the emerging research themes. Olawumi and Chan (2018) define the scientometric analysis as a technique that allows for a broader capturing of a scientific field by identifying research frontiers and structural patterns using formulae and visualizations. By using scientometrics as a method of analysis, it is possible to determine the underlying dynamics in any scientific field (Soydal, 2010; Yalcin, 2010), and the authors, institutions, and countries that direct the field (Yalcin and Yayla, 2016). According to Konur (2012), 
scientometric analysis is one of the most used methods to examine the development and performance of an identified research field. To see more applications of scientometrics, you can refer to (Charvet et al., 2011; Velmurugan and Radhakrishnan, 2015; Olawumi and Chan, 2018).

To reach the goal of this study, we used the Web of Science (WoS) as the data source. SCM publication data was gathered from WoS using the query TS = ("supply chain management"). There is a total of 13477 records found between the years 1998 to 2017. The breakdown of types of publications is provided in Figure 1. The highest percentage $(59.38 \%)$ of SCM publications are articles, followed by proceeding paper that ranks the second highest percentage (31\%). Other publications, including book, review, and book chapter, are of a small percentage (less than 5\%).

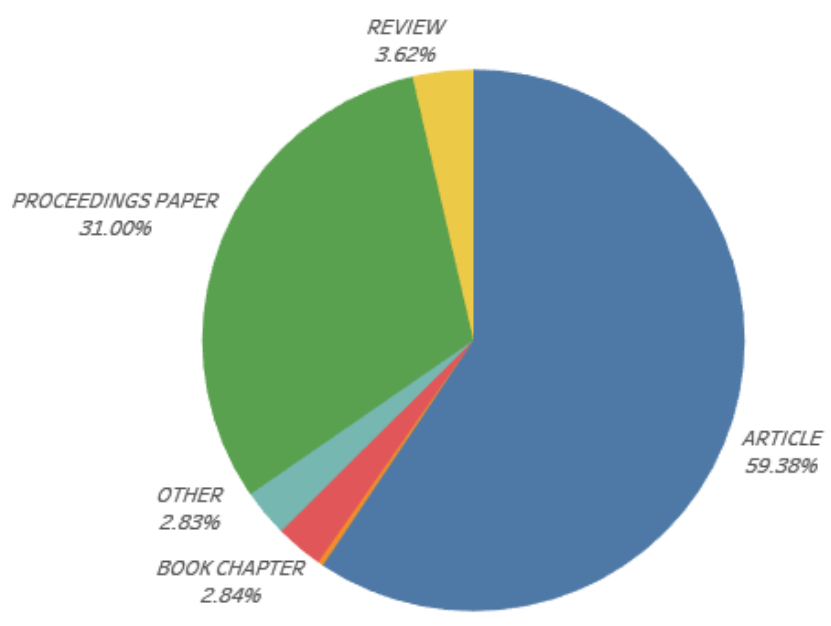

Figure 1 Breakdown of types of publications

There is a total of five scientometric analysis carried out in this study: (1) The most productive scholars in terms of the number of publications and citations; (2) The most productive countries that have produced the most research in the field; (3) The most productive organizations contributing to SCM studies; (4) The core journals for SCM in terms of the number of citations and h-index values; (5) The keyword clusters that assist in capturing the shifted research interest and focus in the SCM area.

To track research trends over time and deduce emerging research topics, the papers reviewed are categorized into three stages based on the period of publication. The main sources or anchor points for each period were determined by using the Main Path Analysis (Hsiao et al., 2015; Olczyk, 2016; Ho et al., 2017; Henrique, Sobreiroand Kimura, 2018; Lee et al., 2018) on the SCM literature. The findings for each period bring value to this paper.

\section{RESULTS}

This section discusses the results of this study's scientometric analysis as described in Section 3. Particularly, an analysis was conducted on the number of publications and the number of citations to identify the most productive authors, institutions, and countries in the field of SCM. Also, a list of core journals in the field is determined using Bradford's Law. To better understand the existing SCM literature, this study conducted the keyword cluster analysis on the published studies aiming to make inferences about the topics that have been discussed most frequently in the field. An evaluation of the results with a systematic analysis of the SCM literature is presented.

\section{A. The Most Productive Scholars}

The number of publications have been taken into consideration to determine the productivity of authors in the field of SCM. Table 1 summaries the results and ranks the top 15 scholars based on their number of publications. It is observed that the researchers with collaborations have relatively more publications. From Table 1, we can see that the most productive scholars including Sarkis J., Gunasekaran A., and so forth have far more multi-authored papers than the single-authored papers. It might be because of the multi-disciplinary structure of the field. Besides the number of publications, influence of scholars can be assessed by looking at the number of citations. For example, Zhu Q.H. is ranked 8th on the list but highly influential in the field in terms of total number of citations.

Table 1 The most productive scholars

\begin{tabular}{|c|c|c|c|c|c|c|}
\hline $\begin{array}{l}\text { 总 } \\
\text { 苑 }\end{array}$ & 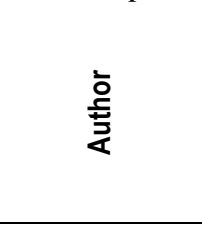 & 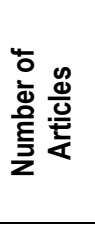 & 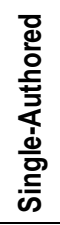 & 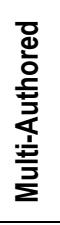 & 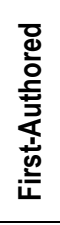 & 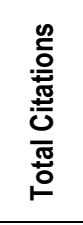 \\
\hline 1 & Sarkis J. & 76 & 6 & 70 & 6 & 1175 \\
\hline 2 & Gunasekaran A. & 72 & 2 & 70 & 24 & 1298 \\
\hline 3 & Govindan K. & 71 & 3 & 68 & 25 & 563 \\
\hline 4 & Choi T.M. & 56 & 16 & 40 & 16 & 300 \\
\hline 5 & Cheng T.C.E. & 46 & 0 & 46 & 5 & 74 \\
\hline 6 & Lai K.H. & 40 & 0 & 40 & 8 & 355 \\
\hline 7 & Seuring S. & 40 & 4 & 36 & 7 & 162 \\
\hline 8 & Zhu Q.H. & 37 & 1 & 36 & 24 & 2278 \\
\hline 9 & Chan F.T.S. & 37 & 1 & 36 & 14 & 592 \\
\hline 10 & Kumar S. & 34 & 1 & 33 & 16 & 275 \\
\hline 11 & Liu Y. & 32 & 0 & 32 & 14 & 130 \\
\hline 12 & Zhao X.D. & 31 & 0 & 31 & 6 & 346 \\
\hline 13 & Carter C.R. & 29 & 3 & 26 & 14 & 23 \\
\hline 14 & Xiao T.J. & 28 & 0 & 28 & 14 & 206 \\
\hline 15 & Jabbour C.J.C. & 28 & 2 & 26 & 5 & 134 \\
\hline
\end{tabular}

\section{B. The Most Productive Countries}

In order to examine the countries which have produced the most research in the field, the number of publications is considered. The extent of collaboration is represented using indicators of intra-country (SCP) and inter-country (MCP) collaboration (see Table 2). It is noteworthy that, for the top 15 countries listed in Table 2 , the intra-country collaboration contribute to the majority of the publications. Table 2 also includes the total number of citations for each country and their average citation per article. The top three countries in the list also have the highest total number of citations. The three countries that stand out the most in the list are the 
United States, China, and Canada. The United States ranks highest for all metrics listed in the table. China ranks the second in terms of number of publications but with a relatively low average article citations of 10.32 while Canada, although ranks 9th in terms of number of publications, has the second highest average citations per article.

Table 2 The most productive countries

\begin{tabular}{|c|c|c|c|c|c|c|}
\hline 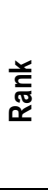 & $\begin{array}{l}\text { 䒿 } \\
\text { ơ }\end{array}$ & 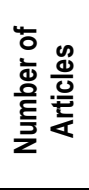 & 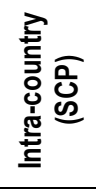 & 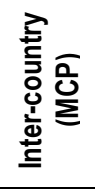 & 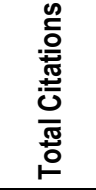 & 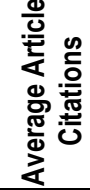 \\
\hline 1 & USA & 2389 & 1893 & 496 & 85403 & 35.75 \\
\hline 2 & China & 2256 & 1858 & 398 & 23272 & 10.32 \\
\hline 3 & United Kingdom & 823 & 559 & 264 & 19986 & 24.28 \\
\hline 4 & Taiwan & 597 & 498 & 99 & 10942 & 18.33 \\
\hline 5 & Germany & 559 & 425 & 134 & 11011 & 19.70 \\
\hline 6 & India & 507 & 449 & 58 & 5876 & 11.59 \\
\hline 7 & Italy & 342 & 262 & 80 & 5987 & 17.51 \\
\hline 8 & Iran & 325 & 286 & 39 & 3684 & 11.34 \\
\hline 9 & Canada & 302 & 187 & 115 & 8077 & 26.75 \\
\hline 10 & Spain & 288 & 196 & 92 & 5258 & 18.26 \\
\hline 11 & Australia & 283 & 172 & 111 & 3922 & 13.86 \\
\hline 12 & Korea & 254 & 194 & 60 & 3776 & 14.87 \\
\hline 13 & France & 232 & 144 & 88 & 3756 & 16.20 \\
\hline 14 & Netherlands & 228 & 158 & 70 & 5259 & 23.07 \\
\hline 15 & Malaysia & 223 & 174 & 49 & 1593 & 7.14 \\
\hline
\end{tabular}

\section{The Most Productive Universities}

Universities are the leading institutions for scientific research, so it is important to look at their productivity in the SCM field. The most productive universities are ranked in terms of number of publications. The results are presented in Table 3 which also includes information on citations. Citations not only reflect the quality of the research papers but also measure the impact of the study. Although there are several parameters used in the citation analysis, one of the most commonly used one is the h-index. The h-index briefly refers to the intersection point of the number of publications and the number of citations (Jokic, 2009). In the previous section, it was noted that the United States and China are at the top of the list when it comes to the most productive countries. Though Iran is ranked 8th on the country list (Table 2), Islamic Azad University located in Iran is ranked second in the list of most productive universities shown in Table 3. It is worth mentioning that when the relevant ranking is taken in terms of number of citations and h-index values, the rank order will be different. Universities in China (particularly Hong Kong), which is on the top of the list in terms of the number of publications, exhibit remarkable performances both in terms of number of publications and their impact factors.
Table 3 The most productive universities

\begin{tabular}{|c|c|c|c|c|c|}
\hline 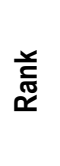 & 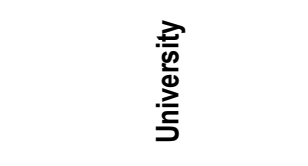 & 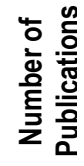 & 语 & 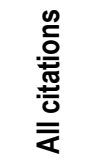 & 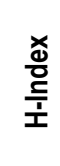 \\
\hline 1 & Hong Kong PolytechUniv & 346 & 6917 & 11539 & 55 \\
\hline 2 & Islamic Azad Univ & 169 & 1481 & 2126 & 27 \\
\hline 3 & Michigan State Univ & 149 & 4497 & 5951 & 41 \\
\hline 4 & Arizona State Univ & 145 & 6194 & 7620 & 43 \\
\hline 5 & Univ Tennessee & 120 & 3118 & 4050 & 33 \\
\hline 6 & Cardiff Univ & 94 & 1817 & 2413 & 27 \\
\hline 7 & Univ Hong Kong & 89 & 1604 & 2128 & 29 \\
\hline 8 & Univ Tehran & 86 & 911 & 1152 & 22 \\
\hline 9 & Univ Arkansas & 85 & 1597 & 2070 & 23 \\
\hline 10 & Ohio State Univ & 83 & 4177 & 4667 & 30 \\
\hline 11 & Univ Nottingham & 82 & 812 & 1151 & 18 \\
\hline 12 & Univ Southern Denmark & 82 & 1976 & 2500 & 27 \\
\hline 13 & City Univ Hong Kong & 81 & 1757 & 2126 & 28 \\
\hline 14 & Beijing JiaotongUniv & 80 & 314 & 349 & 10 \\
\hline 15 & Indian Inst Technol & 80 & 1171 & 1615 & 9 \\
\hline
\end{tabular}

\section{Core Journals for SCM}

To determine the most important journals for SCM, metrics for both the number of publications and the citation values of the journals were considered. The result is summarized in Table 4.

Table 4 Core journals for SCM

\begin{tabular}{|c|c|c|c|c|}
\hline 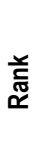 & 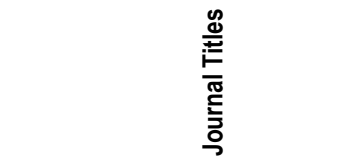 & 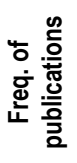 & 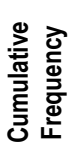 & 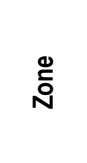 \\
\hline 1 & SUPPLY CHAIN MANAG. & 96 & 96 & Zone 1 \\
\hline 2 & EUR. J. OPER. RES. & 82 & 178 & Zone 1 \\
\hline 3 & INT. J. PROD. ECON. & 78 & 256 & Zone 1 \\
\hline 4 & INT. J. OPER. PROD. MANAGE. & 61 & 317 & Zone 1 \\
\hline 5 & INT. J. PROD. RES. & 41 & 358 & Zone 1 \\
\hline 6 & IND. MANAGE. DATA SYST. & 39 & 397 & Zone 1 \\
\hline 7 & MANAGE. SCI. & 39 & 436 & Zone 2 \\
\hline 8 & PROD. OPER. MANAG. & 38 & 474 & Zone 2 \\
\hline 9 & PROD. PLAN. CONTROL & 37 & 511 & Zone 2 \\
\hline 10 & J. OPER. MANAG. & 35 & 546 & Zone 2 \\
\hline 11 & IND. MARK. MANAGE. & 28 & 574 & Zone 2 \\
\hline 12 & INTERFACES & 21 & 595 & Zone 2 \\
\hline 13 & J. OPER. RES. SOC. & 20 & 615 & Zone 2 \\
\hline 14 & COMPUT. CHEM. ENG. & 18 & 633 & Zone 2 \\
\hline 15 & TRANSP. RES. PT. E-LOGIST. & 18 & 651 & Zone 2 \\
\hline 16 & INT. J. TECHNOL. MANAGE. & 17 & 668 & Zone 2 \\
\hline 17 & DECIS. SCl. & 16 & 684 & Zone 2 \\
\hline 18 & COMPUT. IND. ENG. & 13 & 697 & Zone 2 \\
\hline
\end{tabular}




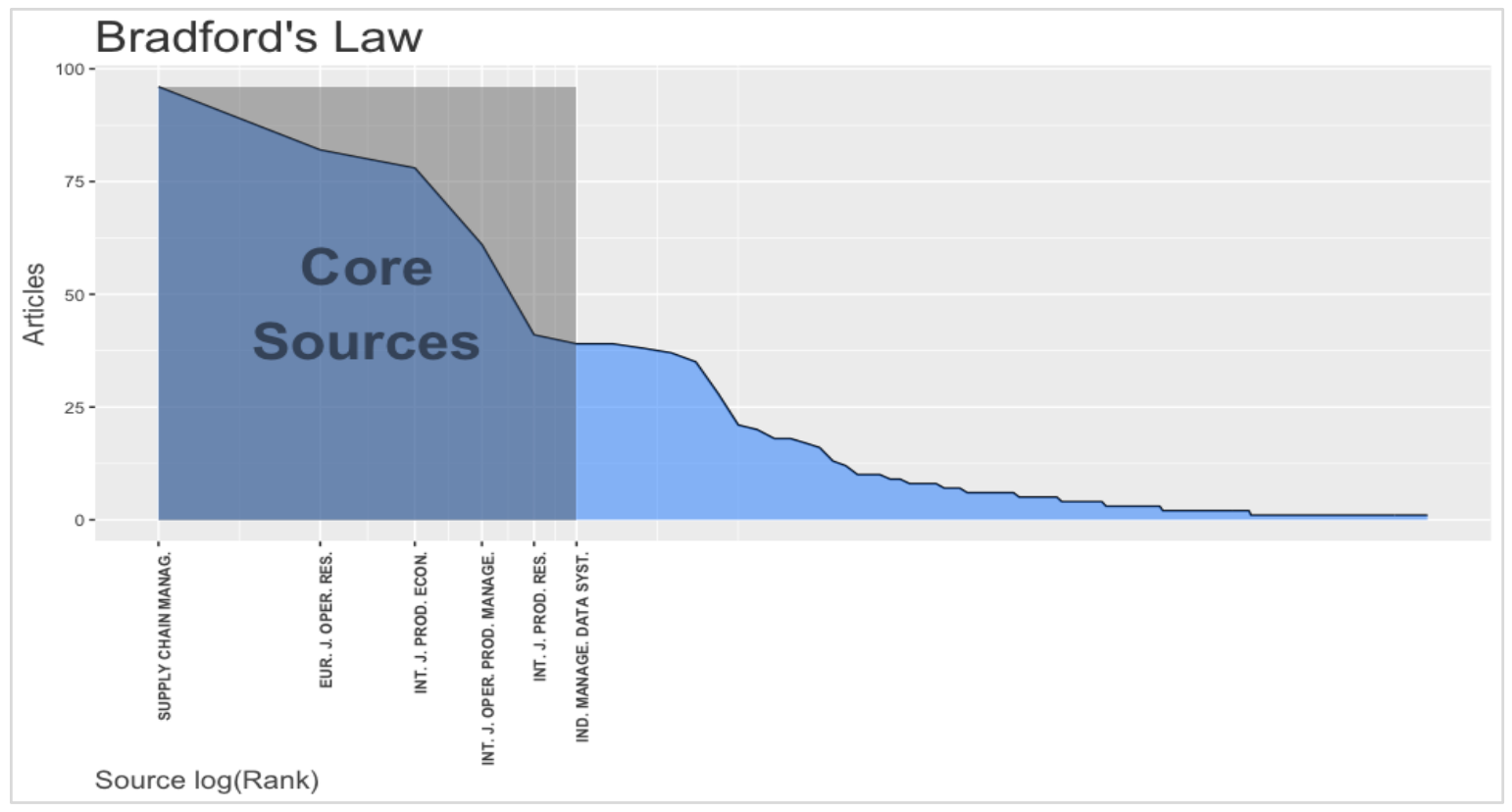

Figure 2. Core SCM Journals using Bradford's Law

Bradford's Law of Scattering is a law of diminishing returns and scattering (Nash-Stewart et al., 2012). Bradford et al. (1953) claimed that "there are a few very productive periodicals, a larger number of more moderate producers, and a still larger number of constantly diminishing productivity". In other words, a small number of journals provide the basic and essential content necessary for the relevant discipline. By using this law, we can divide the scholarly journals into two zones in terms of the number of publications. The journals in the first zone constitute core journals in the field (see Figure 2).

\section{E. Research Trends and Emerging Research Topics in SCM}

Figure 3 shows the trend in quantity of articles published in the field of SCM since the year 1990. We can see mild growth in publications in the early years before 2005 and a steady growth between the years 2006 and 2013 while a geometric growth between the years 2014 and 2017.
Given the very few publications between the years 1990 to 1997, we start our trend analysis from the year 1998. Based on the growth rate of research publications, the data has been divided into three periods.

- Period 1: 1998-2005 (mild rate of increase)

- Period 2: 2006-2013 (steady rate of increase)

- Period 3: 2014-2017 (geometric rate of increase)

The research publications were then clustered in terms of the various supply chain topics. Each cluster was named and ranked in terms of the number of publications so that research trends and emerging topics at different periods can be identified. Keywords assigned to the papers were used to identify the topics frequently discussed in the field. The keywords were compiled according to their frequency of usage, and then size reduction techniques with multiple correspondence analysis (MCA) are also utilized. We used $\mathrm{R}$ programming language to draw a conceptual structure of the field and K-means clustering to identify clusters of papers studying common subjects. Results are shown as twodimensional maps in Figures 4-6.

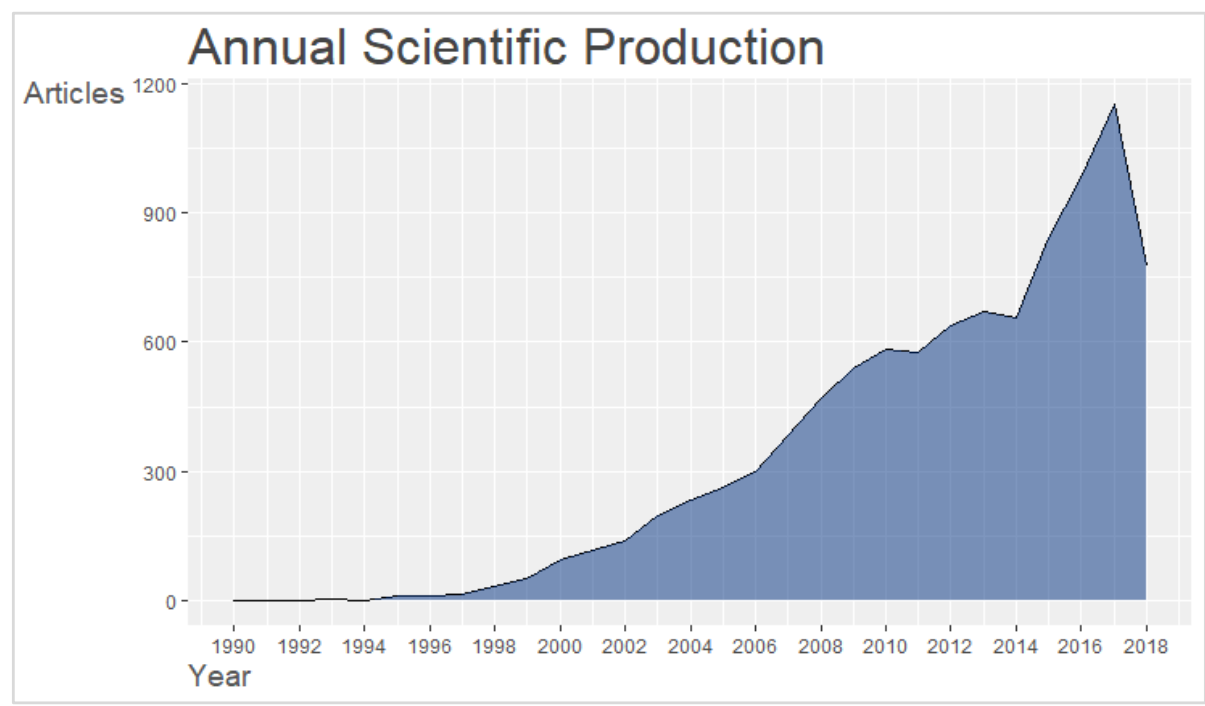

Figure 3 SCM publishing trends 


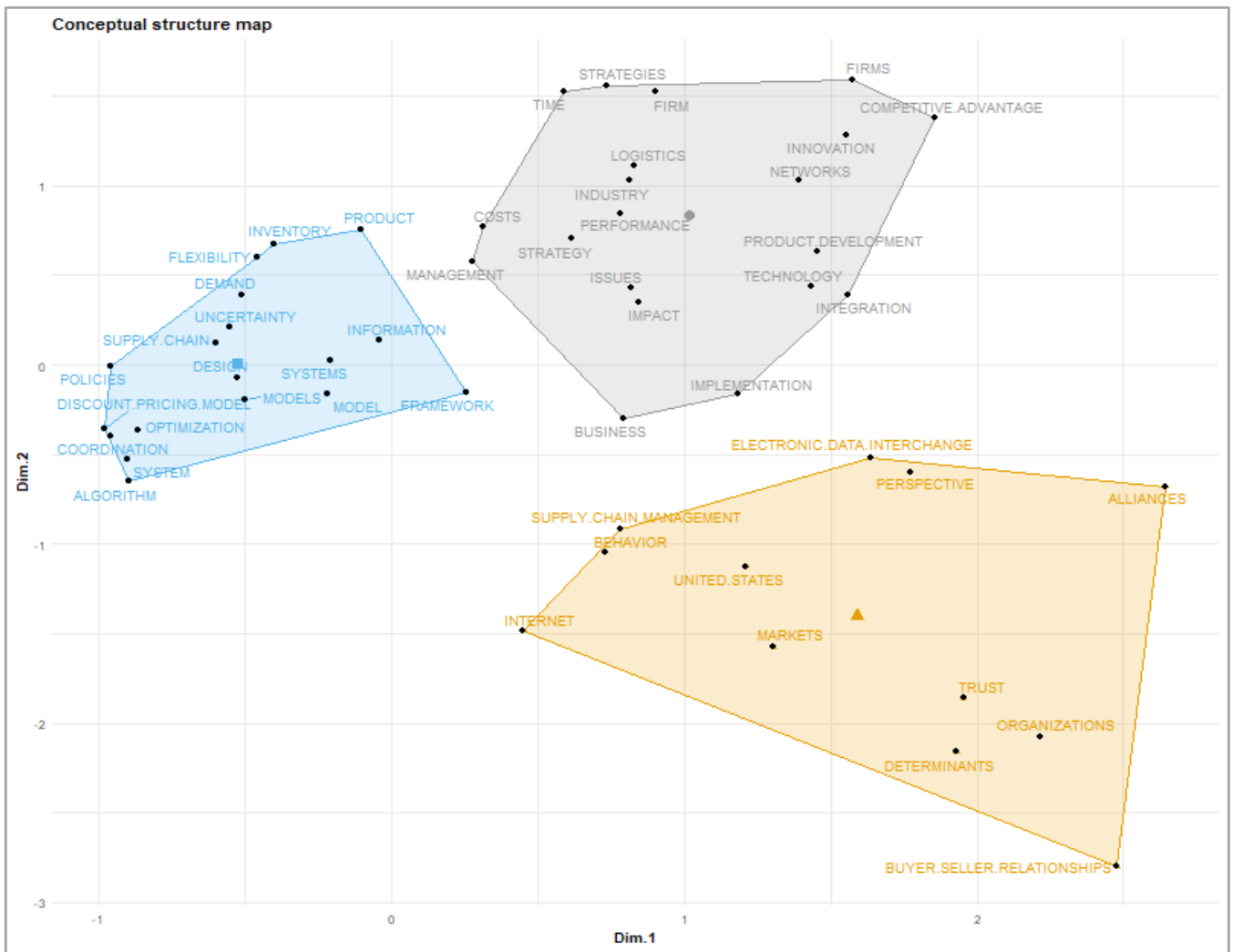

Figure 4 1998-2005 most discussed topics by MCA

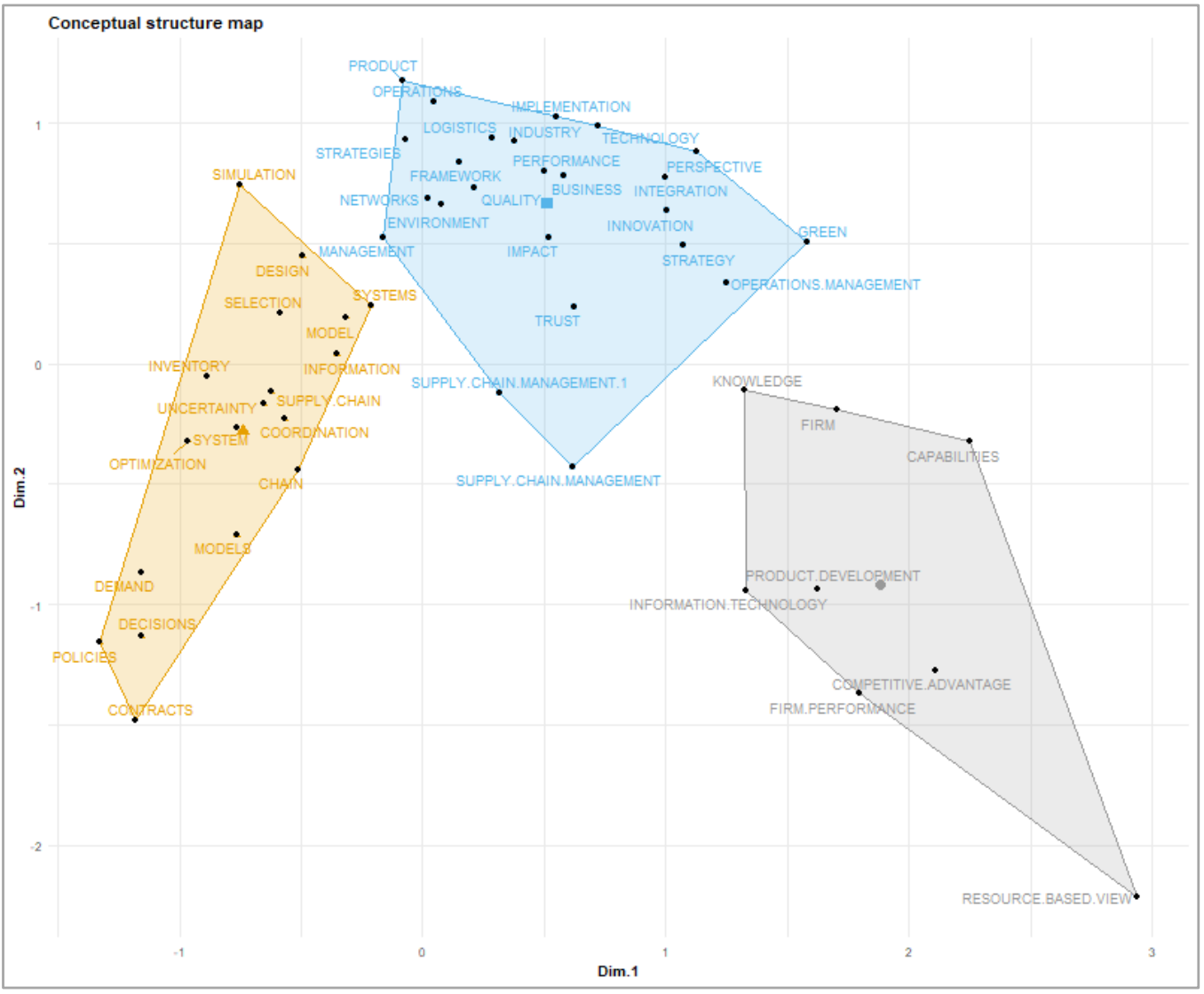

Figure 5 2006-2013 most discussed topics by MCA 


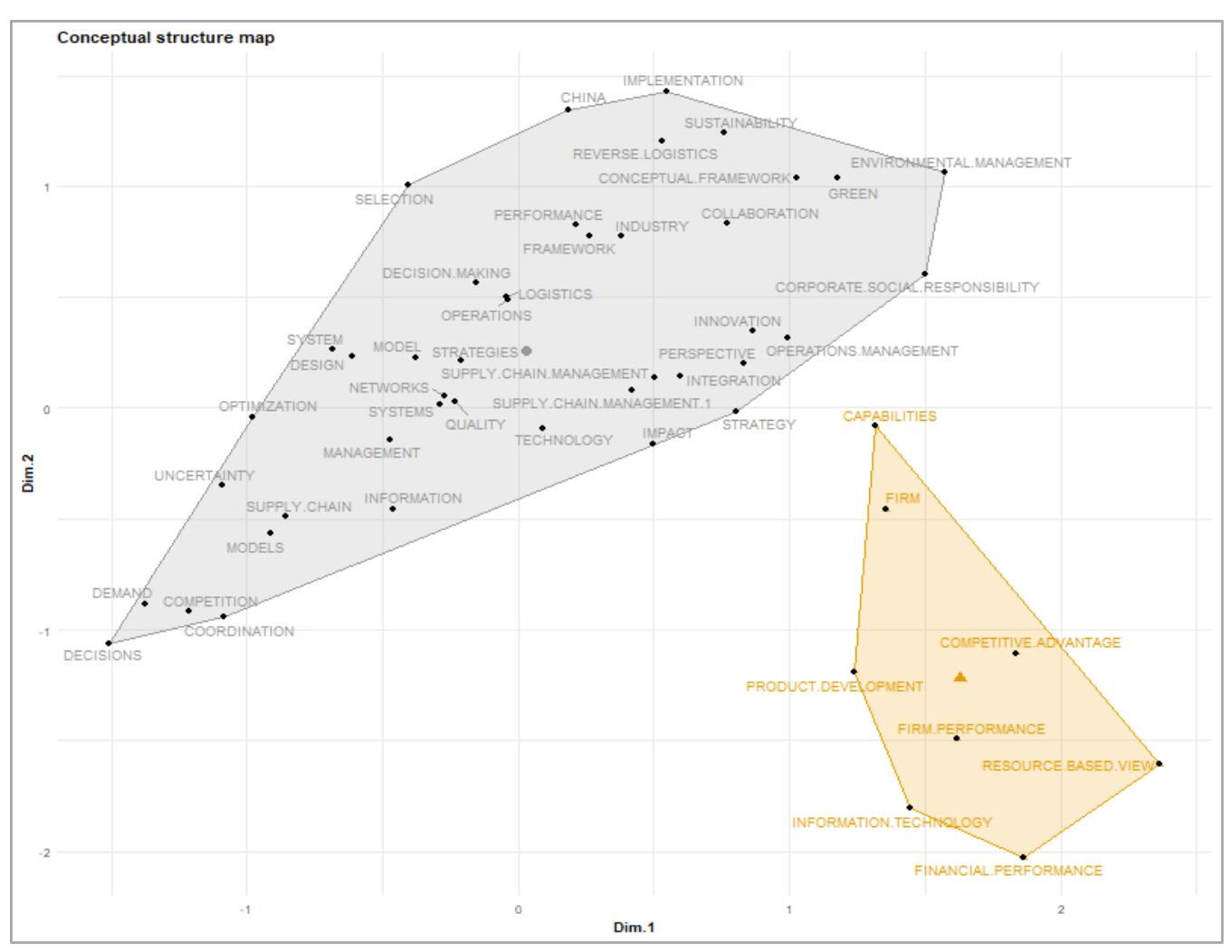

Figure 6 2014-present most discussed topics by MCA

From Figures 4-6, we can summarize the clusters and draw the main research topics for each period. A wide range of topics are studied in each period. Some supply chain management topics, including competitive advantage and strategy, coordination and innovation, risk management, and information technology, are explored throughout the entire study period. The list below summarizes the topics that were found to be distinctively prevalent during each time period.

- Period 1: inventory management, cost reduction, firm performance

- Period 2: supply chain contracts, integration, risk management

- Period 3: social responsibility, environmental/green, reverse logistics, working capital

SCM topics in the first period of scholarly work begin with a focus on competitive advantages such as lowering cost and improving customer service (Tan et al.,1998; Lambert and Cooper, 2000; Horvath, 2001). Then, along with globalization and increased supply chain complexity, more attention is paid to coordination and contracts ( $\mathrm{Li}$ and Liu, 2006; Shin and Benton, 2007; Chick et al., 2008; Lee and Rhee, 2011), integration (Yao et al., 2007; Flynn et al.,2010;Chatzoudes and Chatzoglou, 2011), and risk management (Manuj and Mentzer, 2008; Sodhi et al.,2012; Astuti et al., 2013). At this point, the concept of green supply chain starts to emerge in the literature. In the most recent period (period 3), the evolution of SCM has shifted its focus to enterprise social responsibility (Hsueh, 2014; New, 2015; Quarshie et al.,2016; Fenget al.,2017), reverse logistics (Soleimani and Govindan, 2014; Alshamsi and Diabat, 2015),further development of green supply chain (Govindan et al., 2014; Tundys and Rzeczycki, 2015; Li et al.,
2016), and working capital optimization (Silvestro and Lustrato, 2014; Lind et al., 2016; Liu and Zhou, 2017). Characterized by the articles published during the study period, Period 1 tends to focus on initial theoretical and conceptual framework studies that help describe the field. Taking more established theories in SCM, Period 2 starts to advance the research by empirically testing and quantitative modeling. Period 3 continues putting forward the novel framework and advanced quantitative methodologies applied in the field. With such a strong knowledge base being available today, the future SCM studies are expected to continue to grow for the next coming years.

\section{CONCLUSION}

The studies on SCM have consistently received global attention and consideration from both scholars and practitioners. Organizations choose to cooperate with other entities in the supply chain and develop partner relationships to improve their global market competitiveness. This study employs the scientometric method to analyze 13477 WoS bibliographic records between the years 1998 to 2017, where top productive scholars, institutions, countries, and a list of core journals were identified. We also explored the research interest changes the field has undergone in the past few decades by performing keyword clusters analysis.

This study reveals a general increase in the number of publication records over the years, which shows that more efforts are devoted to supply chain management and development. Also, as regards general productivity among scholars, we found Joseph Sarkis, Angappa Gunasekaran, and Kannan Govindan are the top three lead scholars in the field. Although Qinghua Zhu does not have many 
publications, Qinghua Zhu received the highest citation. Meanwhile, in terms of the distribution of the publications on SCM, the majority of articles are from the United States, China, United Kingdom, Taiwan, and Germany. The United States not only has the most significant number of publications but also the highest total number of citations. Hong Kong Polytech University, Islamic Azad University, Michigan State University, Arizona State University, and the University of Tennessee are the top five productive institutions in SCM research work.

This study also reveals a list of core journals that contribute significantly to SCM literature by using Bradford's law, including Supply Chain Management, European Journal of Operational Research, International Journal of Production Economics, International Journal of Operations \& Production Management, International Journal of Production Research, and Industrial Management \& Data Systems. The identified core journal list can be used to monitor the SCM literature and development effectively.

Furthermore, cluster analysis was used in this study to examine the focus of SCM research topics in three different time periods. In the first period (1998-2005), research mostly focuses on inventory management, cost reduction, and firm performance, whereas in the second period (2006-2013), supply chain contracts, integration, and risk management are heavily explored. In the third period (2014-2017), the focus shifts towards the concepts of social responsibility, green supply chain, reverse logistics, and working capital optimization. Findings reveal the evolution of SCM research field from conceptual frameworks to the actualization through quantitative modeling and empirical testing methods.

This study provides valuable information to the academics and industry practitioners in the field of SCM, where an in-depth understanding of the literature structure, research themes, critical scholars, institutions, and trending topics are presented with illustrative diagrams. The scientometric analysis provides an accurate description of the global picture of SCM research. Meanwhile, considering big data, cloud computing, artificial intelligence, autonomous vehicles, and reduction of carbon footprint are widely pursued in today's digitalization revolution, it is recommended for researchers to pay more attention to the emerging trends as well as how to further utilize these up-todate technologies to benefit SCM development.

There are limitations in this research. Firstly the data set used was retrieved from the WoS database only. A natural revenue for further research is to seek more data sources beyond WoS. Additionally, the scientometric results and inferences in the study are based on the publication data obtained through a single query. While we consider the query used to be proper for retrieving the publication data, we acknowledge that expanding the queries to include a wide variety of keywords could bring a more comprehensive review of the field. Future research expansion in this direction would involve many other contributing works for more research findings.

\section{ACKNOWLEDGEMENT}

The authors would like to thank the anonymous reviewers for their constructive comments that greatly improved the manuscript.

\section{FUNDING}

This work was supported by the Scientific and Technological Research Council of Turkey Postdoctoral Research Programme (TUBITAK BIDEP 2219) [1059B191700840].

\section{REFERENCES}

Ahi, P.,and Searcy, C. (2013). A comparative literature analysis of definitions for green and sustainable supply chain management. Journal of Cleaner Production52, pp.329-341.

Ahi, P., Searcy, C., and Jaber, M. Y. (2016). Energy-related performance measures employed in sustainable supply chains: A bibliometric analysis. Sustainable Production and Consumption 7, pp.1-15.

Alshamsi, A. and Diabat, A. (2015). A reverse logistics network design. Journal of Manufacturing Systems 37(3), pp. 589-598.

Al, U., Soydal, I., and Yalcin, H. (2010). An Evaluation of the Bibliometric Features of bilig (in Turkish). Bilig 55, pp.1-20.

Astuti, R., Marimin, M., Arkeman, Y., Poerwanto, R., and Meuwissen, M. P. (2013). Risks and risks mitigations in the supply chain of mangosteen: a case study. Operations and Supply Chain Management: An International Journal 6(1), pp. 11-25.

Bradford, S.C., Egan, M.E, and Shera, J.H. (1953). Documentation. 2nd ed. London, UK: Crossby Lockwood.

Baatz, E.B. (1995). CIO 100 - Best practices: the chain gang. CIO 8, pp.46-52.

Chien, M.K., and Shih, L.H. (2007). An empirical study of the implementation of green supply chain management practices in the electrical and electronic industry and their relation to organizational performances. International Journal of Environmental Science and Technology 4(3), pp.383-394.

Chick, S., Mamani, H., and Simchi-Levi, D. (2008). Supply Chain Coordination and Influenza Vaccination. Operations Research 56(6), pp. 1493-1506.

Charvet, F. F., Cooper, M. C., and Gardner, J. T. (2011). The intellectual structure of supply chain management: A bibliometric approach. Journal of Business Logistics 29(1), pp.47-73.

Chatzoudes, D., and Chatzoglou, P. (2011). The Impact of 360 Supply chain integration on operational and business performance. Operations and Supply Chain Management: An International Journal 4(2/3), pp. 145-156.

Colicchia, C., \& Strozzi, F. (2012). Supply chain risk management: a new methodology for a systematic literature review. Supply Chain Management: An International Journal 17(4), pp. 403-418.

Cooper, M.C., Lambert, D.M., and Pagh, J.D. (1997). Supply chain management: more than a new name for logistics. The International Journal of Logistics Management 8(1), pp.1-14.

Farley, G.A. (1997). Discovering supply chain management: a roundtable discussion. APICS-The Performance Advantage7(1), pp.38-39.

Fahimnia, B., Sarkis, J., and Davarzani, H. (2015). Green supply chain management: A review and bibliometric 
analysis. International Journal of Production Economics 162, pp. 101-114.

Feng, Y., Zhu, Q., and Lai, K.H. (2017). Corporate social responsibility for supply chain management: A literature review and bibliometric analysis. Journal of Cleaner Production 158, pp. 296-307.

Flynn, B., Huo, B., and Zhao, X. (2010). The impact of supply chain integration on performance: A contingency and configuration approach. Journal of Operations Management 28(1), pp. 58-71.

Gelsomino, L. M., Mangiaracina, R., Perego, A., and Tumino, A. (2016). Supply chain finance: a literature review. International Journal of Physical Distribution \& Logistics Management 46(4), pp. 348-366.

González-Benito, J., Lannelongue, G., and Alfaro-Tanco, J. A. (2013). Study of supply-chain management in the automotive industry: a bibliometric analysis. International Journal of Production Research 51(13), pp.3849-3863.

Govindan, K., Kaliyan, M., Kannan, D., and Haq, A. N. (2014). Barriers analysis for green supply chain management implementation in Indian industries using analytic hierarchy process. International Journal of Production Economics 147, pp. 555-568

Gupta, S., Altay, N., and Luo, Z. (2017). Big data in humanitarian supply chain management: a review and further research directions. Annals of Operations Research, pp.1-21.

Habib, M.M. (2017). Supply Chain Management (SCM): its implications on manufacturing and service industry. Proc. Of The Sixth Intl. Conf, On Advances In ESSHBS, Thailand, pp.55-60.

Henrique, B. M., Sobreiro, V. A., and Kimura, H. (2018). Building direct citation networks. Scientometrics 115(2), pp. 817-832.

Ho, W., Zheng, T., Yildiz, H., \&Talluri, S. (2015). Supply chain risk management: a literature review. International Journal of Production Research 53(16), pp. 5031-5069.

Horvath, L. (2001). Collaboration: the key to value creation in supply chain management. Supply Chain Management 6(5), pp. 205-207.

Ho, M. H. C., Liu, J. S., and Chang, K. C. T. (2017). To include or not: the role of review papers in citationbased analysis. Scientometrics 110(1), pp.65-76.

Hsueh, C.F. (2014). Improving corporate social responsibility in a supply chain through a new revenue sharing contract. International Journal of Production Economics 151, pp.214-222.

Hsiao, C. H., Tang, K. Y., and Liu, J. S. (2015). Citationbased analysis of literature: a case study of technology acceptance research. Scientometrics 105(2), pp. 10911110 .

Jacobs, F. R., and Chase, R. (2017). Operations and Supply Chain Management: The Core, 4th ed. (pp. 17-19). New York, US: McGraw-Hill Education.

Jokić, M. (2009). H-index as a new scientometric indicator. Biochemia Medica 19, pp.5-9.

Kazemi, N., Modak, N. M., \& Govindan, K. (2018). A review of reverse logistics and closed loop supply chain management studies published in IJPR: a bibliometric and content analysis. International
Journal of Production Research 57(15-16), pp. 49374960.

Konur, O. (2012). The evaluation of the global research on the education: A scientometric approach. ProcediaSocial and Behavioral Sciences 47, pp. 1363-1367.

Kumar, A., and Kushwaha, G.S. (2015). Bibliometric Analysis of Supply Chain Management: An International Journal from 2005-2014. International Journal of Supply Chain Management 4(2), PP. 90-105.

Lambert, D. M., and Cooper, M. C. (2000). Issues in supply chain management. Industrial Marketing Management 29(1), pp. 65-83.

Lee, T. S., Lee, Y. S., Lee, J., and Chang, B. C. (2018). Analysis of the intellectual structure of human space exploration research using a bibliometric approach: Focus on human related factors. Acta Astronautica 143 , pp.169-182.

Lee, C. and Rhee, B. (2011). Trade credit for supply chain coordination. European Journal of Operational Research 214(1), pp. 136-146.

Li, J. and Liu, L. (2006). Supply chain coordination with quantity discount policy. International Journal of Production Economics 101(1), pp.89-98.

Li, B., Zhu, M., Jiang, Y., and Li, Z. (2016). Pricing policies of a competitive dual-channel green supply chain. Journal of Cleaner Production 112, pp. 20292042.

Lind, L., Monto, S., Kärri, T., and Schupp, F. (2016). Detecting working capital models in the ICT supply chains. International Journal of Supply Chain and Inventory Management 1(3), pp. 233-249.

Liu, X., and Zhou, L. (2017). The Role of An Orchestrator of 3PLs In Supply Chain Finance: A Conceptual Framework. Operations and Supply Chain Management: An International Journal 10(1), pp. 1724.

Luo, J., Ji, C., Qiu, C., and Jia, F. (2018). Agri-food supply chain management: Bibliometric and content analyses. Sustainability 10(5), pp.1573.

Manavalan, E., and Jayakrishna, K. (2019). A review of Internet of Things (IoT) embedded sustainable supply chain for industry 4.0 requirements. Computers \& Industrial Engineering 127, pp.925-953.

Manuj, I. and Mentzer, J.T. (2008). Global Supply Chain Risk Management. Journal of Business Logistics29(1), pp. 133-155.

Mishra, D., Gunasekaran, A., Papadopoulos, T., and Childe, S. J. (2018). Big Data and supply chain management: a review and bibliometric analysis. Annals of Operations Research 270(1-2), pp.313-336.

Mishra, D., Gunasekaran, A., Papadopoulos, T., and Hazen, B. (2017). Green supply chain performance measures: A review and bibliometric analysis. Sustainable Production and Consumption 10, pp.85-99.

Nash-Stewart, C.E., Kruesi, L.M., and Mar, C.B.D. (2012). Does Bradford's Law of Scattering predict the size of the literature in Cochrane Reviews? Journal of the Medical Library Association 100(2), pp.135-138.

New, S.J., and Payne, P. (1995). Research frameworks in logistics: three models, seven dinners and a survey. International Journal of Physical Distribution and Logistics Management 25(10), pp.60-77. 
New, S. (2015). Modern slavery and the supply chain: the limits of corporate social responsibility? Supply Chain Management 20(6), pp. 697-707.

Olawumi, T. O., \& Chan, D. W. (2018). A scientometric review of global research on sustainability and sustainable development. Journal of Cleaner Production 183, pp. 231-250.

Oliver, R., and Webber, M.D. (1982). Supply-chain management: logistics catches up with strategy.

Olczyk, M. (2016). A systematic retrieval of international competitiveness literature: a bibliometric study. Eurasian Economic Review 6(3), pp.429-457.

Quarshie, A.M., Salmi, A., and Leuschner, R. (2016). Sustainability and corporate social responsibility in supply chains: The state of research in supply chain management and business ethics journals. Journal of Purchasing and Supply Management 22(2), pp. 82-97.

Schoenherr, T., and Speier-Pero, C. (2015). Data science, predictive analytics, and big data in supply chain management: Current state and future potential. Journal of Business Logistics 36(1), pp. 120132.

Şen, A. (2008). The US fashion industry: a supply chain review. International Journal of Production Economics 114(2), pp. 571-593.

Shin, H. and Benton, W.C. (2007). A quantity discount approach to supply chain coordination. European Journal of Operational Research 180(2), pp. 601-616.

Shi, W. (2016). Coordinating Supply Chain Financing. ProQuest Dissertation Publishing.

Shiau, W. L., Dwivedi, Y. K., and Tsai, C. H. (2015). Supply chain management: exploring the intellectual structure. Scientometrics 105(1), pp. 215-230.

Sodhi, M.S., Son, B., and Tang, C.S. (2012). Researchers' Perspectives on Supply Chain Risk Management. Production and Operations Management 21(1), pp. 113.

Shi, W., and Drzymalski, J. (2017). Non-cooperative game theory analysis in supply chain internal financing. Proceedings of the 2017 Industrial and Systems Engineering Conference, Pittsburgh, US, pp.549-554.

Silvestro, R., and Lustrato, P. (2014). Integrating financial and physical supply chains: the role of banks in enabling supply chain integration. International Journal of Operations \&Production Management 34(3), pp. 298-324.

Soleimani, H. and Govindan, K. (2014). Reverse logistics network design and planning utilizing conditional value at risk. European Journal of Operational Research 237(2), pp. 487-497.

Tan, K.C. (2001). A framework of supply chain management literature. European Journal of Purchasing \& Supply Management 7(1), pp.39-48.

Tan, K.C., Kannan V.R., and Handfield R.B.(1998). Supply Chain Management: Supplier Performance and Firm
Performance. International Journal of Purchasing \& Materials Management 34(3), pp. 2-9.

Tate, W. L., Ellram, L. M., and Kirchoff, J. F. (2010). Corporate social responsibility reports: a thematic analysis related to supply chain management. Journal of Supply Chain Management 46(1), pp. 19-44.

Tundys, B., and Rzeczycki, A. (2015). Construction of green supply chain for organic products. Operations and Supply Chain Management: An International Journal 8(1), pp. 37-47.

Velmurugan, C., \& Radhakrishnan, N. (2015). 'Literature output of Supply Chain Management: A Scientometric approach. Journal of Organizational Behavior 3(2), pp. 31-44.

Vousinas, G. (2018). Supply chain finance revisited: A critical review with future prospects. SSRN Electronic Journal, pp. 1-28.

Wang, Y., Han, J.H., and Beynon-Davies, P. (2019). Understanding blockchain technology for future supply chains: a systematic literature review and research agenda. Supply Chain Management: An International Journal 24(1), pp.62-84.

Wang, J. J., Chen, H., Rogers, D. S., Ellram, L. M., and Grawe, S. J. (2017). A bibliometric analysis of reverse logistics research (1992-2015) and opportunities for future research. International Journal of Physical Distribution \& Logistics Management 47, pp. 666-687.

Wen, X., Choi, T.M., and Chung, S.H. (2019). Fashion retail supply chain management: A review of operational models. International Journal of Production Economics 207, pp.34-55.

Xu, X., Chen, X., Jia, F., Brown, S., Gong, Y., \& Xu, Y. (2018). Supply chain finance: A systematic literature review and bibliometric analysis. International Journal of Production Economics 204, pp.160-173.

Yalcin, H. (2010). Bibliometric Profile of Journal of National Folklore (2007-2009) (in Turkish). MilliFolklor 85, pp.205-211.

Yao, Y., Evers, P., and Dresner, M. (2007). Supply chain integration in vendor-managed inventory. Decision Support Systems 43(2), pp. 663-674.

Yalcin, H., and Yayla, K. (2016). Main Dynamics of Folklore Discipline: a Scientometric Analysis. Milli Folklor 112, pp.42-60.

Yalcin, H., and Yayla, K. (2016). Scientometric Analysis of the Researches About Technological Pedagogical Content Knowledge and Scholarly Communication. Egitim Ve Bilim-Education and Science 41(188), pp.291-307.

Yalcin, H., and Yayla, K. (2016). A Strategy Proposal for the Journals Published in the Social and Human Sciences. Tarih Incelemeleri Dergisi 31, pp.609-638.

Zhang, X., Song, H., and Huang, G.Q. (2009). Tourism supply chain management: A new research agenda. Tourism Management 30(3), pp.345-358.

Dr. Haydar Yalcin is an Assistant Professor in the Department of Information Management of Izmir Katip Celebi University in Izmir, Turkiye. His research interests are scientific productivity measurement, bibliometric analysis, big data applications for extracting patterns to direct information and technology policy. His works appeared in many professional journals and books. He serves as a faculty member of the PSU Chapter of the Omega Rho International Honor Society (Portland, USA). $\mathrm{He}$ is also a member of UNESCO Turkey's Experts Committee of Memory of the World and the technical editor of Journals of (TUBA-AR and TUBA KED) Turkish Academy of Sciences. 
Dr. Wanying Shi earned her Ph.D. in Engineering Management from Western New England University (Massachusetts, USA) in 2016. Her research interests include operations management, quantitative decision making, and supply chain management. She is a visiting professor with The School of Business at Portland State University in Portland, USA. She has been invited to become a faculty member of the PSU Chapter of the Omega Rho International Honor Society. She serves as a reviewer for journals such as IEEE Access, Sustainability Accounting, Management and Policy Journal. She is currently serving on the Editorial Review Board for IEEE Transactions on Engineering Management.

Dr. Zafrin Rahman is an Instructor in Management at Portland State University, with over 14 years of experience in teaching, business/investment management and research. With a B.A. in Economics from Wellesley College, she worked for over 8 years as an Associate Portfolio Manager at wealth management firms managing emerging market investment portfolio in private and public equities. She later earned her $\mathrm{PhD}$ in Business Administration with a focus on Strategic Management and Entrepreneurship from Washington State University. Her research and teaching focus are in the areas of strategy, entrepreneurship and innovation. 